\title{
TRIGGERING FACTORS OF AN ACUTE ISCHEMIC STROKE: A CASE CROSSOVER STUDY FROM PAKISTAN
}

\author{
Qamar ZAMAN*, Maimoona SIDDIQUI*, Kinza WAQAR**, Naveen ZAIDI* \\ *Shifa international Hospital, Department of Neurology, Islamabad, PAKISTAN \\ **National University of Medical Sciences, Department of Neurology, Rawalpindi, PAKISTAN
}

\begin{abstract}
INTRODUCTION: Various 'well-known' risks for ischemic stroke include DM, HTN, smoking and obesity. Recently various factors have been identified that can trigger the ischemic stroke events. Several studies have shown that the stroke can be triggered by negative mood changes, infections, activity, and dietary factors in some cases. The identification of common triggers can be helpful in preventing the vascular events in those at risk.

METHODS: : It was a case-crossover study. Exposure to the triggers like emotions, amount and type of the food, excessive alcohol use, smoking, weather changes and travelling were compared at the index period of 2 hours and average exposure during the control periods of 24 hours and 1 month before the event. Descriptive statistics, odd ratios and confidence interval were calculated for exposure during the index and the control period.

RESULTS: There were 128 participants, with about $68 \%$ male and $32 \%$ female. Odds of triggering the ischemic event for exposure to the any of the triggers at the index period compared to the exposure during the control period were 2.6. Odds were of 3.11 for infection, 1.18 for the travel and 18.14 for the negative emotions. No significant odds were found for the excessive alcohol intake, smoking, weather changes or amount or type of the food taken at index period vs. control period. DISCUSSION and CONCLUSION: Exposure to the certain triggers like infection, travelling and negative emotions at the index period of 2 hours compared to the exposure at the control period carries the high odds of triggering the ischemic stroke.
\end{abstract}

Keywords: Stroke, triggers, negative emotions, PANAS scale.

\section{AKUT İSKEMIK İNMEYI TETIKLEYEN FAKTÖRLER: PAKISTAN'DAN BIR ÇAPRAZ VAKA KONTROL ÇALIŞMASI}

\section{ÖZET}

GİRIŞ ve AMAÇ: İskemik inmeyi tetiklediği iyi bilinen bazı faktörler DM, HT, sigara kullanımı ve obezitedir. İskemik olayları tetikleyebilen yeni bazı faktörler belirlenmiştir. Çeşitli çalışmalar bazı vakalarda inmenin negatif duygu durum değişiklikleri, enfeksiyon, aktivite ve beslenme ile ilișkili faktörler ile tetiklenebileceğini göstermişlerdir. Bu tetikleyicilerin belirlenmesi vasküler olayların önlenmesine yardımcı olabilir.

YÖNTEM ve GEREÇLER Bu çalıșma bir çapraz vaka kontrol çalıșmasıdır. Duygular, yiyeceklerin tipi ve miktarı, aşırı alkol kullanımı, sigara kullanımı, hava değişiklikleri, seyahat gibi tetikleyicilere maruz kalma durumu 2 saatlik indeks döneminde ve olaydan önceki 24 saatlik ve 1 aylık kontrol periyotlarındaki ortalama maruz kalma süresi ile karşılaştırıldı. Tanımlayıcı istatistikler, odds oranları ve güven aralıkları hesaplandı.

BULGULAR: 128 katılımcı çalışmaya alındı; \%68'i erkek, \%32'si kadındı. Kontrol periyodu süresi ile karşılaştırıldığında, 2 saatlik indeks periyodu sırasında herhangi bir tetikleyiciye maruz kalma için bir iskemik olay tetikleyicisinin odds oranı 2.6 idi. Odds oranları enfeksiyon için 3.11, seyahat için 1.18 ve negatif duygular için 18.14 idi. Așırı alkol tüketimi, sigara kullanımı, hava durumu değişiklikleri veya yiyecek tipi veya miktarı için indeks periyottaki ve kontrol periyodundaki odds oranlarında anlamlı farklılık bulunmadı.

TARTIŞMA ve SONUÇ: Kontrol periyoduna kıyasla, 2 saatlik indeks periyodu sırasında enfeksiyon, seyahat ve negatif duygular gibi bazı tetikleyicilere maruz kalmak inmenin tetiklenmesi için yüksek olasılık taşımaktadır.

Anahtar Kelimeler: İnme, tetikleyici, negatif duygular, PANAS skalası. 


\section{INTRODUCTION}

The ischemic stroke ranks 3rd among the all causes of the death, and each year 795,000 people experience new or recurrent strokes in the USA. Out of them about 610,000 are the new and 185,000 are recurrent strokes. It is estimated that after an average of every 40 second someone in the United States had a stroke event (1). Although few studies are available from South Asia and Pakistan about the stroke, according to a recent update annual incidence of stroke in Pakistan is 250 per 100,000 populations, and which projects to the estimate of 350,000 strokes per year (2). According to the recent study done in Karachi, which estimates the lifetime prevalence of stroke to be $21.8 \%$ in individuals aged 35 or older (3). Similarly, another study reported the prevalence of stroke in northern areas of Pakistan to be $4.8 \%$ with the mean age of onset at 45 years (4). In Southeast Asia, about $10-15 \%$ of strokes occur in younger population (5). In Pakistan, about $26 \%$ of stroke patients were between the 15-45 years of age (6).

Risk factors associated with stroke are 'wellknown' and include non-modifiable factors like age, sex, race, and modifiable risk factors like diabetes mellitus, hypertension, smoking, obesity and dyslipidemias (7). Recently, studies have shown that various events which although do not cause stroke per se can trigger acute event of the ischemic stroke. Various factors being studied include infections, anger, negative emotions, the sudden change in the posture, nose blowing $(8,9)$.

Little data has been found in the Pakistani population regarding the specific triggering factors for the stroke or transient ischemic attack (TIA). The aim of our study was to identify the pertinent triggering factors in our population so that efforts are made to reduce the exposure in those at the risk. Also, we aimed to compare the exposure to the various triggers at the index period of 2 hour before the acute stroke event compared to the average exposure during the 24 hours and 1 month before the event and calculate their odds of triggering the events.

\section{MATERIAL AND METHODS}

It was a case-crossover study of 1-year duration done at stroke unit Shifa International Hospital Islamabad after taking an approval from the IRB Shifa International Hospital. The sample size was calculated by W.H.O sample size calculator relative precision was taken as $50 \%$, confidence level 95\%, expected prevalence of outcome in absence group 50\%, expected odds ratio (10), ratio of presence to absence was taken as 1 , on using the formulae na $=[\mathrm{Z} \alpha / 22 / \log 2(1$ $\mathrm{RP})]^{*}[1 / \mathrm{X}+1 / \mathrm{Y}]$ sample size came out to be 128 . All the participants fulfilling the inclusion criteria were recruited using simple non-probability sampling technique. Written and informed consent was taken and the participants were asked about the risk factors for the stroke, duration of symptoms and type of the stroke was determined. They were asked about their exposure to the triggering factors which includes the history of fever or infection, excessive smoking or alcohol, history of travelling, type and amount of food, change in weather recently or any specific change in posture or physical activity. They were asked about the positive or negative emotions according to the positive and negative emotions affect scale (PANAS) (11) (Annex A). Each patient acted as his own control and relative exposure at index period of 2 hours before the stroke event were compared to the exposure at the control periods of 24 hours and 1 month before the event.

We included following patients in the study; (a) all the patients presenting with an ischemic stroke within 1-4 days diagnosed by clinical features and imaging, (b) patients should be able to communicate, (c) patients with previous stroke and having Modified Rankin Scale (MRS) score more than 3. The following patients were excluded from the study; (a) patients with previous dementia or cognitive decline, (b) patients having aphasia, (c) two or more strokes with MRS score greater than 2-3, (d) patients with an acute confusional state.

\section{Statistical Analysis}

Descriptive statistics were calculated for variables like age, gender, co-morbids, type of the stroke, and exposure to the specific triggers using the online statistical data analyzer. Relative frequencies and percentages were calculated for exposure to the any of the trigger during the index period compared to the both control periods. Relative frequencies, percentages, Odd ratios (OR), Relative risk (RR) and confidence interval (CI) were calculated for the combined and each individual triggers. 


\section{RESULTS}

About 420 patients were admitted with the ischemic stroke during the study period. About 37 participants were excluded due to low education and difficulty in understanding the questionnaire and few unwilling to participate. About 265 participants didn't meet the inclusion criteria and finally, 128 were included in the study.

Out of the 128 Patients, the majority were male $(68 \%)$ compared to the females (32\%) as shown in Table I. Mean age of the participants was $64.02 \pm 13.53$. About $11 \%$ of the participants were found to be in the young stroke category having age less than the 45 years.

Hypertension and Diabetes mellitus were the most common risk factors, found in the majority of the participants followed by coronary artery disease and smoking. About 15 participants had other co-morbid unrelated to the cardiovascular risks. Descriptive statistics for various risk factors are shown in Figure I.

Large artery MCA infarct constituted about 46 $\%$ of all the stroke, followed by the lacunar infarcts $24 \%$, then posterior circulation infarcts $8 \%$ followed by ACA and cardio-embolic infarcts. In $9 \%$ of the cases, the exact cause of the stroke could not be determined. Frequencies of various stroke types are shown in Figure II.

Our results showed that about 31 (24\%) had a stroke after exposure to the any of the trigger during the index period only with no history of exposure at the any of the control periods. while $14(10 \%)$ were only exposed at the control periods with no history of the exposure at the index period.

Considering the individual triggering factors, about $17(13 \%)$ reported the history of infection in the 2 hour period compared to $6(4.5 \%)$ of the participants reporting any infections only in the control period and about $14(10 \%)$ reporting it in the both periods. Exposure to unusual travelling in triggering the ischemic stroke event was observed in $23(17 \%)$ during the 2 hour period compared to 20 (15\%) having travel history in the control period.In our study, exposure to the negative emotions was observed in 16 (12\%) participants during the 2 hour period before the stroke compared to the only 1 participant in the control period. Relative frequencies for exposure to the various triggers during the index and the control period are shown in Table II.
Table I. Showing the frequency of the participants according to the gender and age.

\begin{tabular}{|c|c|c|}
\hline Variables & No. of the participants (n) & Percentages \\
\hline Gender: Total & 128 & \\
\hline Male & 87 & $68 \%$ \\
\hline Female & 41 & $32 \%$ \\
\hline \multicolumn{3}{|l|}{ Age } \\
\hline$>45$ years & 113 & $85 \%$ \\
\hline$<45$ years & 15 & $15 \%$ \\
\hline
\end{tabular}

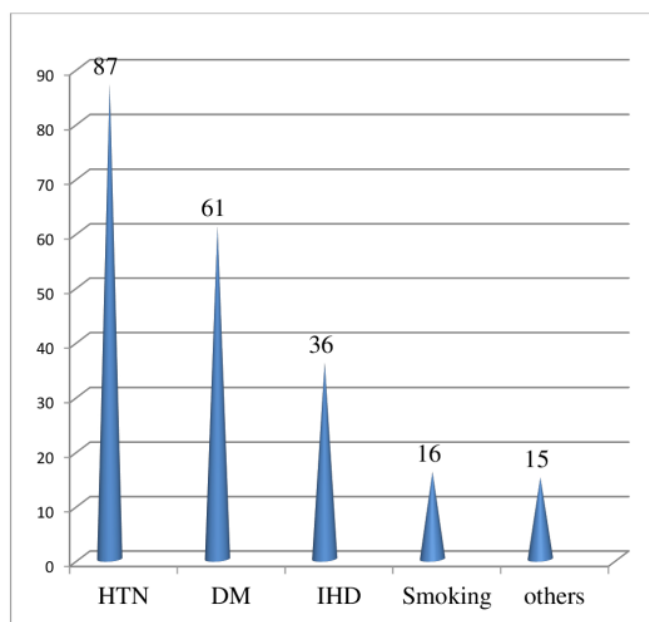

Figure I. Showing the participants according the risk factors of having ischemic stroke.

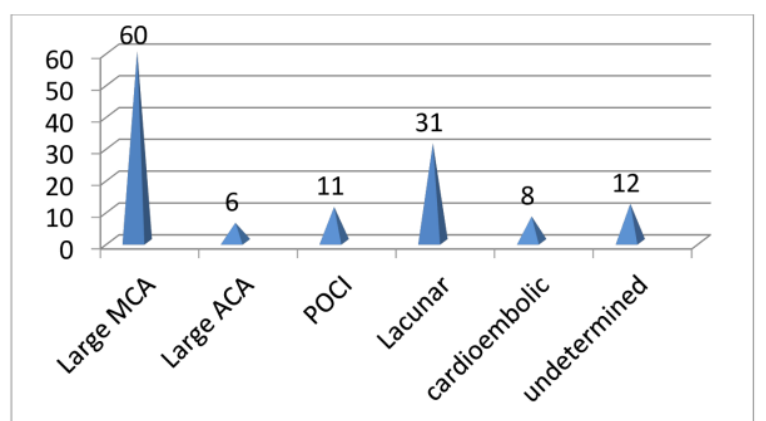

Figure II. Showing the frequency of various types of stroke.

Odd of triggering the stroke for the any of the trigger when present during the index period only compared to the presence at the control period only or being exposed at both time period was only 2.6 (95\% CI, 1.30-5.17), RR=2.2 (95 \%CI 1.23-3.96). Odds were 3 (95\% CI 1.18-8.1) RR=2.8 (95\% CI 1.15-6.95) for the infections, with the unusual travelling having the OR 1 (95\% CI 0.612.28) $\mathrm{RR}=1$ (95\% CI 0.66-1.98), the negative emotions having the OR 18 (95\% CI 2.3-139) $\mathrm{RR}=16$ (95 \% CI 2.15-118.86). 
Table II. Showing the frequency of the participants according to the gender and age.

\begin{tabular}{llllll}
\hline Triggers & $\begin{array}{l}\text { Exposed at } \\
2 \text { hours }\end{array}$ & $\begin{array}{l}\text { Exposed at } \\
24 \text { hours }\end{array}$ & $\begin{array}{l}\text { Exposed at } \\
1 \text { month }\end{array}$ & $\begin{array}{l}\text { Exposed at both } \\
\text { control period }\end{array}$ & $\begin{array}{l}\text { Exposed at both index } \\
\text { and control periods }\end{array}$ \\
\hline Exposed to any trigger & $31 / 128$ & $4 / 128$ & $11 / 128$ & $14 / 128$ & $53 / 128$ \\
& $(24 \%)$ & $(3 \%)$ & $(8 \%)$ & $(10 \%)$ & $(41 \%)$ \\
Infection & $17 / 128$ & $4 / 128$ & $2 / 128$ & $6 / 128$ & $14 / 128$ \\
& $(13 \%)$ & $(3 \%)$ & $(1.5 \%)$ & $(4 \%)$ & $(11 \%)$ \\
Travel & $23 / 128$ & $5 / 128$ & $15 / 128$ & $20 / 128$ & $3 / 128$ \\
Negative emotions & $(18 \%)$ & $(4 \%)$ & $(12 \%)$ & $(16 \%)$ & $(2 \%)$ \\
& $16 / 128$ & $0 / 128$ & $0 / 128$ & $0 / 128$ & $31 / 128$ \\
\end{tabular}

No increase odds were found for the smoking, alcohol intake, food, activity, change in the temperature and the lack of positive emotions. Relative odds for the various trigger is shown in Figure III.

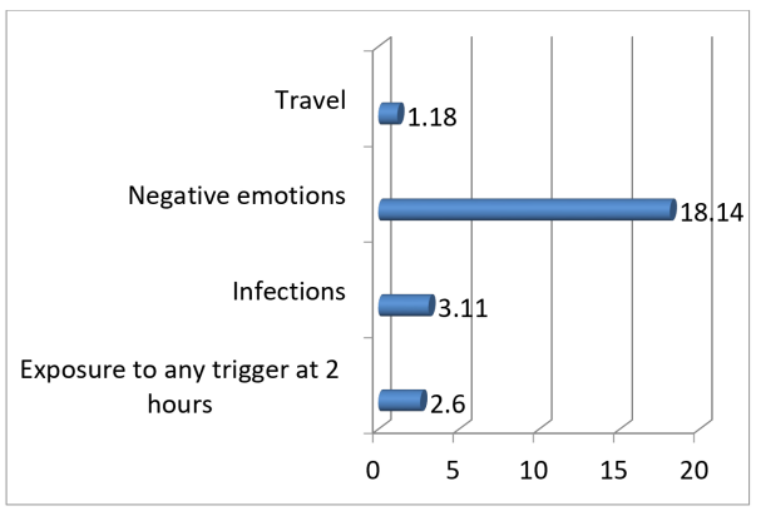

Figure III. Showing the odds of various triggers in triggering ischemic stroke.

\section{DISCUSSION}

It was a case-crossover study design in which each patient acted as his control by comparing exposure at 2 hours, 24 hours and 1 month. Our hypothesis was that exposure to the specific triggering factors during the index 2 hours period before the ischemic event carry high odds of triggering it compared to the exposure only during the control period of 24 hours and previous 1 month before or exposure to the trigger at both control and index time. In our study odds for exposure to any of the triggers at 2 hour time was 2.6 and RR of 2.2, compared to exposure during the control period only, showing that the exposure, especially during 2 hours time, carries the high odds of triggering the event compared to the exposure during the control period. The previous study also found significantly elevated odds for an acute onset of stroke during the 2-hour hazard period, compared to the control period of a day before the onset of the stroke and the patient's usual exposures during the last year. About 38\% reported exposure to at least one potential triggering factor during the 2 hour hazard period before the onset of a stroke symptoms, compared to $4.5 \%$ patients exposed during the control period the day before. The OR for patients exposed to at least one potential triggering factor during the 2hour hazard period was 8 when compared with exposure during previous 24 hours and was 27 compared to the annual exposure (8). In another study, some unusual events 24 hours prior to the onset of stroke was experienced by 44 (31.4\%) subjects (9). Odds were $3, \mathrm{RR}=2.8$ for exposure to the infections in the index period compared to control period. In comparison, the previous study showed the history of injury or illness in one week prior to the onset of stroke was reported by $22 \%$ subjects. Among them, $38 \%$ had a fever and $16 \%$ of the subjects had a fever associated with other illness like a cough, diarrhoea or injury (9).

Travelling within 2 hours had OR $1, \mathrm{RR}=1$ compared to the control period. Although unusual sudden posture changes were observed as trigger in various studies, none reported the sudden posture changes as a trigger in our study, while one study reported OR of 24 (8), for the sudden posture changes, a startling event had OR of 12 (8). Another study reported the stroke in association with sexual intercourse or laughter (10). In another study about thirty-six percent of the strokes occurred while the subjects squatted, mostly during the act of defecation (11).

In our study, the exposure to the negative emotions in the index period had the OR of 18 and RR of 16 compared to the control period. When compared with the previous studies, one of the studies showed that the negative emotions carried the highest odds 35 for triggering such events (8). In another study unusual mental stress was the trigger in about $29(65.9 \%)$ of the subjects (9). One study showed the relative risks forthe negative and the positive emotional experiences in 
triggering an acute coronary event when exposed during the first hour were 14 and 3.5 respectively and the relative risk was found to be 9 for an episode of anger. Using conditional logistic regression analysis, the highest relative risk was associated with the negative emotional experiences (12).

In our study, no increase in odds were found for the smoking, alcohol intake, food, activity, change in temperature and the lack of positive emotions, which is similar to the previous study. No significant confounding effect of changes in smoking habits, diet, or medications during the last year was found (8). Another study reported that $16 \%$ of the subjects had smoked, $2 \%$ reported alcohol intake and $11 \%$ of subjects had taken some medicine, 37 (26\%) subjects reported change in their posture two hours prior to the onset of the stroke (9).

Mechanism of triggering stroke in case of emotions could be the increase in stress hormones, increase pulse, BP and sympathetic activity leading to the spasm and triggering thrombo-embolic events. Infections increase the inflammatory markers leading to the thrombotic state. The travelling is also a well-known factor for triggering thrombo-embolism. In the patients having high risk of the stroke, measures should be taken to treat the infections early and promptly, avoiding stress and frequent travelling may also save them from triggering the events.

Strengths of our study were that it was the first study from Pakistan on the triggering factors of stroke. It was a case-crossover design, which exposure bias is reduced by self-comparing the exposure at index and control periods.

Limitations of our study were that simple non-probability sampling technique was used so selection bias may be present. It was a 6 months study and sample size may be less to derive the conclusion. Also, recall bias by the some patients was a limitation of the study.
As conclusion, acute ischemic stroke has been observed to be linked to the several triggers. Infections, travel and negative emotions have shown to carry the high odds of triggering stroke events. Promptly treating infections and efforts to reduce travel and stress control may help in preventing the trigger of acute ischemic stroke in those at the risk.

\section{REFERENCES}

1. Heart Disease and Stroke Statistics--2010 Update: A Report from the American Heart Association. Circulation. 2010; 121:e46-e215

2. Wasay M, Khatri IA, Kaul S. Stroke in South Asian countries. Nature Reviews Neurology 2014; 10:135-143.

3. Kamal, A. K. et al. The burden of stroke and transient ischemic attack in Pakistan: a community-based prevalence study. BMC Neurol. 2009;9 (58)

4. Jafar TH. Blood pressure, diabetes, and increased dietary salt associated with the stroke - results from a communitybased study in Pakistan. Journal of Human Hypertension. 2006; 20: 83-85.

5. Ji R, Schwamm LH, Pervez MA, Singhal AB. Ischemic stroke and transient ischemic attack in young adults: risk factors, diagnostic yield, neuroimaging, and thrombolysis. JAMA Neurol. 2013; 70(1):51-7.

6. Khan JA, Shah MA. Young stroke: Clinical aspects. J Coll Physicians Surg Pak 2000;10:461-66.

7. Hankey GJ. Potential New Risk Factors for Ischemic Stroke. What Is Their Potential?. Stroke.2006; 37: 2181-2188.

8. Koton S, Tanne D, Bornstein NM, Green M. Triggering risk factors for ischemic stroke: a case-crossover study. Neurology. 2004; 63

9. Kumar V, Aggarwal M, Srivastava A. A retrospective study to identify the triggers or precipitants related to the onset of stroke. Nursing and midwifery research journal. 2012;8(2).

10. Pandian JD, Perel R, Robert D. Henderson RD, Sullivan JDO, Stephen J. Read Unusual triggers for stroke j.jocn.2006.04.021

11. Chatterjee SK, Chakravarty A. Is squatting a triggering factor for stroke in Indians?. Acta Neurol Scand. 2002: 105

12. Lipovetzky $\mathrm{N}$ et al. Emotional Events and Anger at the Workplace as Triggers for a First

13. An event of the Acute Coronary Syndrome: A CaseCrossover Study IMAJ 2007; 9:310-315 